\title{
IMPLEMENTATION OF TEACHING MATERIALS USING A REALISTIC MATHEMATICS EDUCATION APPROACH IN PRIMARY STUDENT MATHEMATICS COMMUNICATION
}

\author{
Sylvia Rabbani ${ }^{1}$, Agni Muftianti ${ }^{2}$ \\ ${ }^{1}$ Institut Keguruan dan Ilmu Pendidikan Siliwangi \\ ${ }^{2}$ Institut Keguruan dan Ilmu Pendidikan Siliwangi \\ 1'sylviarabbani@gmail.com, ${ }^{2}$ agnimuftianti@gmail.com
}

\begin{abstract}
The main problem in this study is the lack of student communication skills and the lack of RME-based teaching materials that use used goods as a learning medium. The purpose of this study was to obtain an overview of : 1) learning steps RME using teaching materials and 2). Barriers are felt when learning using these teaching materials. And 3). overview of mathematics communication skill Primary Teacher Education students uses a realistic mathematics education approach with the help of teaching aids made from used materials. The method used is qualitative descriptive. This research was conducted in class A1 and A2 class 2018 for elementary school teacher education students at IKIP Siliwangi for 6 meetings. Data collection techniques in this study were written tests, observations, questionnaires and interviews. In this study, the data analysis technique used is the inductive analysis approach. The results of this study were the steps for implementing elementary mathematics teaching materials in mathematics communication for Primary Teacher Education students.The conclusion from the research that we have done is that there is Primary School Mathematics Learning teaching materials based on the RME approach in Elementary Mathematics Learning courses in fostering mathematical communication skills of Primary Teacher Education students
\end{abstract}

Keywords: Mathematics Communication, Realistic Mathematics Education, Teaching Materials

\begin{abstract}
Abstrak
Masalah utama dalam penelitian ini adalah kurangnya kemampuan komunikasi siswa dan kurangnya bahan ajar berbasis RME yang menggunakan barang bekas sebagai media pembelajaran. Tujuan dari penelitian ini adalah untuk mendapatkan gambaran tentang: 1) langkah-langkah pembelajaran RME dengan menggunakan bahan ajar dan 2). Hambatan dirasakan saat pembelajaran menggunakan bahan ajar tersebut. Dan 3). Gambaran Umum Keterampilan Komunikasi Matematika Siswa Pendidikan Guru Sekolah Dasar menggunakan pendekatan pendidikan matematika realistik dengan bantuan alat peraga yang terbuat dari bahan bekas. Metode yang digunakan adalah deskriptif kualitatif. Penelitian ini dilaksanakan di kelas A1 dan A2 kelas 2018 pada siswa pendidikan guru sekolah dasar di IKIP Siliwangi sebanyak 6 kali pertemuan. Teknik pengumpulan data dalam penelitian ini adalah tes tertulis, observasi, angket dan wawancara. Dalam penelitian ini teknik analisis data yang digunakan adalah dengan pendekatan analisis induktif. Hasil penelitian ini adalah langkah-langkah penerapan bahan ajar matematika SD dalam komunikasi matematika untuk siswa Pendidikan Guru Sekolah Dasar. Kesimpulan dari penelitian yang telah kami lakukan adalah Adanya bahan ajar Pembelajaran Matematika Sekolah Dasar Berbasis Pendekatan Pendidikan Matematika Realistik pada mata kuliah Pembelajaran Matematika SD dalam Membina Keterampilan Komunikasi Matematis Siswa Pendidikan Guru Sekolah Dasar.

Kata Kunci: Komunikasi Matematika, Realistic Mathematics Education, Bahan Ajar
\end{abstract}

\section{INTRODUCTION}

Mathematics learning is one of the subjects that is very important and close to our daily lives. This can be seen from all daily activities related to mathematics. According to de Lange (De Lange, 2004)Mathematics ould be seen as the language that describes patterns - both 
patterns in nature and patterns invented by the human mind. Those patterns can either be real or imagined, visual or mental, static or dynamic, qualitative or quantitative, purely utilitarian or of little more than recreational interest. They can arise from the world around us, from depth of space and time, or the inner workings of the human mind. From the above explanation, we can see that mathematics consists of abstract and concrete concepts that are created from patterns that exist in nature or patterns made by humans.

Mathematics is felt to be very close to our daily lives. Besides, mathematics is also a main subject in formal schools, including elementary schools. Some years ago mathematics thematically presented along with several other subjects. However, this year, Mathematics in Elementary School is partially presented and becomes an independent subject. These changes have an impact on mathematics back into a subject that is considered difficult and frightening by most students, especially elementary students. Some of the problems that occur are low understanding of concepts, problem solving abilities, reasoning skills, and one of them is mathematical communication skills. In line with the results of the study that (Anisa, 2014) students' mathematical communication skills.

Communication is the sending and receiving of messages between two or more people so that the message in question can be understood. Meanwhile, Schoen, Bean, and Ziebarth (Ansari, 2003)suggest that mathematical communication skills are students 'abilities in terms of explaining algorithms and unique ways of solving problems, students' abilities to construct and explain presentations of real-world phenomena in graphs, words or sentences, equations, tables and representations physically. From the above statement, this mathematical communication describes and explains mathematical problems into a more tangible or concrete presentation.

This is in line with the objectives of learning mathematics according to the 2013 Curriculum (Kemendikbud, 2013), namely: increasing intellectual abilities, especially highlevel abilities of students, forming students' abilities in solving problems systematically, obtaining high learning outcomes, training students in communicating ideas, and developing student character. From the explanation above that the benefits of us learning mathematics are not only cognitive or knowledge and affective or attitude. In the above statement, it is stated that mathematical communication skills are one of the high-level intellectual abilities of students. This communication skill is also considered very important for students in solving math problems. 
This communication ability is also the student's ability to connect real objects, pictures, and diagrams into mathematical ideas; explain ideas, situations and mathematical relations either orally or in writing in the form of pictures or graphics; explain and make questions about mathematics that are learned from a given situation (Elida, 2012). In this case, it is explained that this communication skill can be seen from how students can describe a mathematical situation in pictures, graphs, diagrams and others. Also, communication skills can be seen how students explain mathematical situations orally and in writing. There are several problems (Alamiah \& Afriansyah, 2018) in elementary schools that must be addressed immediately, namely those related to the low mathematics communication skills of elementary school students. This also happens to prospective Primary Teacher Educationstudents.

Ratnaningsih (2008) suggests various mathematical learning models that facilitate students in developing mathematical thinking skills such as reasoning, communication, connection, representation, critical, creative, and problem-solving. . From this statement it can be seen that mathematical learning models facilitate the development of mathematical thinking skills, one of which is student mathematics communication (Rokhmani, 2016). One of the learning models commonly used in mathematics learning in Primary School and Primary Teacher Education is Realistic Mathematics Education.

The orientation of RME is: reinvention, the introduction of concepts through concrete issues, or around the student's environment (Pasaribu et al., 2018). RME is a learning process that focuses on the introduction of concrete issues in the environment. In line with Although "realistic" situations in the meaning of "real-world" situations are important in RME, "realistic" has a broader connotation here. It means students are offered problem situations which they can imagine (Tandililing, 2003). From the above statement, it is stated that this realistic condition is explained more broadly when students can imagine the mathematical problems as well as including the mathematical realistic conditions.

Realistic Mathematics Education was developed by Frudental (Streefland, 1991)and Streefland (Streefland, 1991)on mathematics connected reality, mathematics as a human activity and more focused on the substitute of mechanical learning mathematics to be realistic. Gravemeijer (Gravemeijer. K.P.E, 1994) says that mathematics should be cultivated close to the student and must be linked to everyday life. Students are allowed to do the mathematization . It can be concluded that this RME connects the real conditions with the mathematics learning presented by the teacher. It is further revealed that mathematics learning designed by the teacher must be related to the daily lives of students. One of the teacher's efforts in presenting 
meaningful and close to everyday life is the teaching cloth. Therefore, the teacher must be able to design a teaching material that is structured with the RME approach so that the learning presented feels close to students

Teaching materials are a set of materials that are systematically arranged both written and unwritten to create an environment / atmosphere that allows students to learn (Jasmaniah; Fachrurozi; Yeni, 2015). Teaching materials in this research are printed teaching materials in the form of Student Worksheets. The scope of teaching materials to be produced includes (1) Title of Teaching Materials; (2) Learning Indicators; (3) learning objectives; (4) Description of the material; (5) Learning Activities; and (6) Student Activity Sheets. Good teaching materials range from building student knowledge based on experiences in everyday life to finding a mathematical concept (Putri, 2019). modules are an important component in learning because they are used to help obtain information on the subject matter (Parmin, \& Peniati, 2012).

From the statement above, we can see how important the teaching material is to become a medium or bridge in learning to create meaningful learning with a specific purpose. Teaching materials that are arranged must be structured and systematic. This aims to make it easier for students to understand what material is in the book. Teaching materials should also be equipped with teaching materials, evaluation, group worksheets, and individual worksheets. This is done so that the teaching materials prepared are rich in material and evaluations that can measure the extent to which students understand the material presented .

The learning materials are prepared using the Realistic Mathematics Education (RME) approach, beginning with the posing of problems related to the real world of students (Sunismi, 2015). Through real-world problems that students have known, students can find the concepts or principles being studied so that students will better understand the concepts/principles being learned. The teaching materials that are designed begin with contextual problems that are close to everyday life. This is done so that they feel close to the problem and need to solve the problem. With this problem, they were invited to find their concept .

Therefore, researchers research Implementation of Instructional Materials Approach Using Realistic Mathematics Education In Communication Skills Mathematics Student of Primary Teacher Education. The results of this study are expected to foster the communication skills of the students of the Primary Teacher Education IKIP Siliwangi in particular and all the students of the IKIP Siliwangi in general.

\section{METHOD}


This research is a qualitative descriptive study that aims to determine the objective description of the situation regarding the class conditions with all its characteristics. According to Sugiyono (Sugiyono, 2006)that descriptive qualitative research is a research method based on the usual postpositivism philosophy. It is used to investigate under natural objective conditions where the researcher acts as a key instrument. In this descriptive study the teacher/researcher objectively describes the student's abilities, student learning methods , student learning interests, and so on.

The subjects in this study were the A1 class of 2018 class A1 students of Primary Teacher Education IKIP Siliwangi, totaling 35 female students and 5 male students. The students are divided into 3 categories: 1). students who are active and interested in all things new. 2). Students who can follow the lecturer instructions in learning. 3). Less active students. The instruments used in the study were 1). Questionnaire to measure the description of concern for the environment, 2) observation to see the learning situation using teaching materials, 3) interviews to dig deeper information from students about learning using teaching materials in learning environmental awareness.

\section{RESULTS AND DISCUSSION}

\section{Results}

In this section will be exposed right research is done to the student of Primary Teacher Education Siliwangi Teachers' Training College. This research uses descriptive research in which the researcher is required to be able to extract data based on what the data sources say, feel, and do. In qualitative research, the researcher is not what the researcher thinks should be but based on what is happening in the field, experienced, felt, and thought by the data source. By researching approaches descriptive investigator must explain, explain, describe the data that has been obtained by researchers through interviews with informants, as well as through observation and tests.

At the planning stage, this research was conducted in the Elementary School Mathematics Learning course. At this planning stage, the researcher made a lesson plan by adjusting the Realistic Mathematics Education learning steps using the teaching materials for 6 meetings. However, the planning that has been made face-to-face must be turned into an online meeting. This is because of the Covid-19 pandemic , the meeting is made Online. During a pandemic that is being felt by the whole world, especially Indonesia. All who are involved in the world of education do Home Learning (BDR). This resulted in this research being 
conducted online with class A1 class 2018 students. This research was conducted using Google Classroom, Google Meet and Zoom.

This research lasted for 1 month in 4 meetings online (online). There are several materials discussed in these 4 meetings, among others, learning to build flat and building a room for elementary students. Before researching class, our research team made preparations such as consulting with the supervisor of the course, Prof. Josua Sabandar. We conduct online discussions about the research we are going to carry out. Also, we also prepare and compile teaching materials that will be given to students. We provide these teaching materials when learning takes place as a guide and reference in learning.

The first meeting was started by giving a preliminary test on the mathematics communication skills of Primary Teacher Education students. This test aims to measure students' initial communication skills before learning is given. The test contains 10 questions arranged based on indicators of mathematical communication. Students take the test online using Google Classroom. Lecturers can also monitor who has taken the test through the Goolge Classroom through the lecturer's account.

Meetings 2 to 5 are conducted online using Google Meet and Google Classroom. Learning to use RME approach with the following steps, giving the problem, explain the problem, complate the problem, compare and discuss answers and concluded (Hobri, 2010). Each meeting is divided into 3 sessions, the first is an exploration session, in this session the lecturer provides problems, descriptions and simulations on how to provide mathematics learning for elementary students for certain materials. After that students are asked to study the teaching materials that have been given. The second session is the Design stage, students are invited to explain problems, solve problems and create or modify examples of learning mathematics, by changing the steps of learning, media or learning resources. Stages of the design are done outside the network (Offline), self-designing media learning of student and ways how to apply them in learning. At this stage students can look for ideas in the teaching materials that are presented. In the teaching material contains learning steps using media made from unused materials. The last stage is Allot, students are asked to share the results of their designs on social media so that they can be seen by lecturers and their friends in particular and all circles in general.

For an overview of the learning steps in each meeting, the researcher conducted online learning using Google's google meet on Monday April 62020 at 13.00-14.40. The initial step of learning discusses the identification of spatial structures such as cubes and blocks . Before 
the first meeting we already provide information to the students to bring used goods such as food used cardboard, Cardboard former soap, toothpaste cardboard used tools such as scissors, rulers and run. Students are given directions on how to teach elementary school children to teach space identification material. The lecturer invites students to observe objects around in the form of cubes and blocks. M hey also asked to complete the Worksheet shortly geometrical identification . They were also directed to identify the characteristics of ballasts and cubes. It can be seen from the number of sides, corner points and edges. Peacock must also look for other used items in the form of cubes and blocks that are around them.

Stronger assorted waking up space of used cardboard materials are also suggested by the lecturer. How can they turn unused waste into learning media? After the lecturer gives Build Space Araha about it, students are required to create and change the media which has been demonstrated in a lecture earlier. Students are required to be creative in creating learning media innovations from waste. The results of these innovations must be shared on their respective YouTube channels . In this pandemic period, this is one way to evaluate a hang learning te 1 ah we give. Also, this is very useful for other colleagues who need information about mathematics learning media. These activities are carried out until the 4th meeting with different materials each week.

Judging from the results of the pretest and posttest of the Primary Teacher Education students at the IKIP Siliwangi in mathematics communication skills, there was an increase in the results. It can be seen from the pretest average value of students' mathematics communication skills is 61.25. After participating in the learning process, the posttest average score of mathematics communication ability is 75.53 . Besides that, it can be seen the results of the pretest and posttest mathematics communication skills of 40 students in the diagram below.

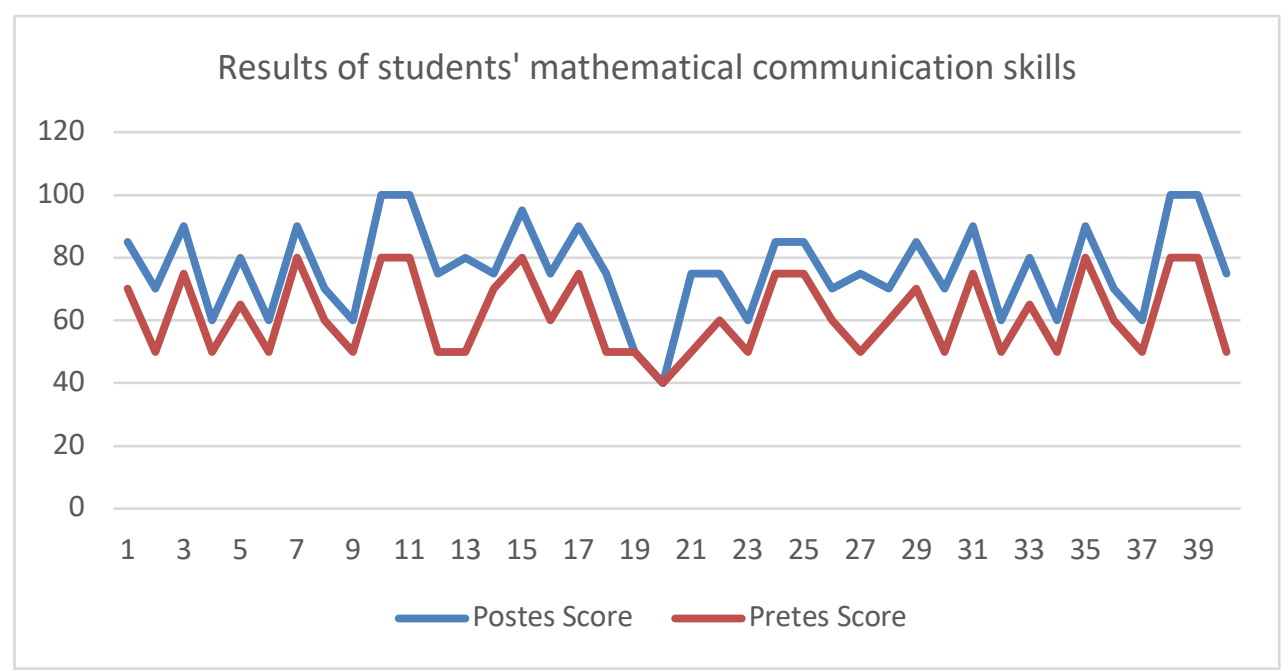

Figure 1. The results of the pretest and posttest of students' mathematical communication skills 
Perceived barriers to researchers in conducting online learning and ofline learning during this pandemic are the unstable signal constraint. Primary Teacher Education Ikip Students of the Siliwangi come from various bloodlines in West Java and its surroundings. The different situations and conditions in each region also greatly affect the smoothness of this research. Sometimes some students have to move places when carrying out lectures online. This is indeed a new thing and we must get used to adapting to technology that makes it easier for us to learn in this pandemic. Lecturers and students are also still groping in using the Video Conference application which is our media in this research. For that we tried it first before carrying out the research. In this case, IKIP Siliwangi makes it easy to access Google Meet by using an email account affiliated with the campus.

Apart from that, the students' diverse conditions in terms of intellectual and understanding were a barrier in itself. Some students use teaching materials that can immediately understand and make innovations in media making. Some use teaching materials still feel confused about how to create learning media for learning mathematics. Therefore lectures are conducted by video conferencing via Google Meets and online discussions via Google Classroom. These two media are quite helpful in the implementation of online lectures in Elementary School Mathematics Learning for Primary Teacher Education students at IKIP Siliwangi.

\section{Discussion}

In Primary School Mathematics Learning course learning goes well and meaningfully by implementing teaching materials and the Realistic Mathematics Education approach. The results of this study are not only theoretically proficient students but also work made to hone their skills in making learning media. This teaching material based on Realistic Mathematics Education is indeed very useful for prospective elementary school teachers because it can become their reference in designing mathematics lessons for elementary school students. In this case the lecturer also previously provided an overview of how to teach some of the material taught in elementary schools. This is in line with the opinion that (Hobri, 2010)Teachers are advised to pay attention to every activity so that all students are actively involved in learning. In addition to lecturers, students also active in creating and recreating their creations according to the notion that they have in designing a learner a mathematical media from recycled materials. By the opinion (Manopo et al., 2018) Students can interact and communicate their ideas. Students communicate the mere idea $\mathrm{k}$ a search for learning design and media as diverse 
as each student has different ideas and unique. In this case, students are required to have high communication skills in solving the mathematical problems presented.

Judging from the mathematics communication ability of the Primary Teacher Education students at the IKIP Siliwangi there is an increase from the pretest to posttest results. There are several indicators of mathematical communication skills that are developed into a research instrument. Sumarmo (Sumarmo, 2002) explained that mathematical communication includes students' abilities: (1) Connecting real objects, pictures, and diagrams into mathematical ideas; (2) Explain mathematical ideas, situations and relations, orally and in writing with real objects, pictures, graphics and algebra; (3) Declare everyday events in language or mathematical symbols; (4) Listening to, discussing, and writing about mathematics; (5) Reading with the understanding of a written mathematics presentation; (6) Make conjecture, preparing arguments. Of the six indicators, the results of the pretest and posttest indicator number 3 are the indicators that get the highest score. This is because in RME learning, it focuses on learning that is close to everyday events (Ubaidillah et al., 2014).

There are several obstacles to the implementation of learning use will include instructional materials, facilities and infrastructure constraints $\mathrm{A}$ are the supported implementation eye learning mathematics Elementary School in this online. This is in line with Pangondian (Pangondian, R. A., Santosa, P. I., \& Nugroho, 2019)which states that among the factors that are the main key to the success of learning in the network is the existence of facilities and infrastructure. (Murni et al., 2019) University and lecturer support is an important factor that supports the success of online learning. This has been done by IKIP Siliwangi by supporting lecturers in carrying out online learning and facilitating lecturers to easily access virtual learning applications. (Rusdiana, E., \& Nugroho, 2020)This online learning is a process of transforming conventional education into digital form so that it has its challenges and opportunities. (Suryani, 2010)The existence of obstacles in the learning process can reduce student interest in learning

\section{CONCLUSION}

The conclusion from the research that we have done is that there is Primary School Mathematics Learning teaching materials based on the Realistic Mathematic Education approach in Elementary Mathematics Learning courses in fostering mathematical communication skills of Primary Teacher Education students. Learning using these Teaching Materials is going well even though it runs online. The obstacle that occurs is related to the 
signal quality of each student, which is different because they conduct online lectures from various regions.

\section{ACKNOWLEDGMENTS}

Thanks to the Ministry of Research, Technology and Higher Education which has provided funding for beginner lecturer research grants (PDP) and who have supported the implementation of this research so that this research can run well

\section{REFERENCES}

Alamiah, U. S., \& Afriansyah, E. A. (2018). Perbandingan Kemampuan Komunikasi Matematis Siswa Antara yang Mendapatkan Model Pembelajaran Problem Based Learning Dengan Pendekatan Realistic Mathematics Education dan Open-Ended. Mosharafa: Jurnal Pendidikan Matematika. https://doi.org/10.31980/mosharafa.v6i2.308

Anisa, W. (2014). Peningkatan Kemampuan Pemecahan Masalah dan Komunikasi Matematik melalui Pembelajaran Pendidikan Matematika Realistik untuk Siswa SMP Negeri di Kabupaten Garut. Jurnal Pendidikan Dan Keguruan, 1(1), 209668.

Ansari, B. I. (2003). Menumbuhkembangkan Kemampuan Pemahaman dan Komunikasi Matematik Siswa Sekolah Menengah Umum (SMU) melalui Strategi Think Talk Write. UPI.

De Lange, J. (2004). Mathematical Literacy for Living from OECD-PISAPerspective. OECDPISA.

Elida, N. (2012). Meningkatkan Kemampuan Komunikasi Matematik Siswa Sekolah Menengah Pertama Melalui Pembelajaran Think-Talk-Write (Ttw). Infinity Journal, 1(2), 178. https://doi.org/10.22460/infinity.v1i2.17

Gravemeijer. K.P.E. (1994). Developing Realistics Mathematics Educations. CD- Press. Hobri. (2010). Metodologi Penelitian Pengembangan [Aplikasi Pada penelitian Pendidikan Matematika]. Pena Salsabila.

Jasmaniah; Fachrurozi; Yeni, E. M. (2015). Bahan Ajar Problem Solving Berbasis Openended Pada Pembelajaran Matematika Untuk Mengembangkan Kemampuan Penalaran Mahasiswa Pgsd. Jurnal Penelitian Pendidikan.

Kemendikbud. (2013). Matematika untuk SD/MI Kuikulum 2013. Depdikbud.

Manopo, M., Sudirman, S., \& Sulandra, I. M. (2018). Pengembangan Bahan Ajar Materi Perbandingan Bercirikan Realistic Mathematics Education. Jurnal Pendidikan: Teori, Penelitian, Dan Pengembangan.

Murni, S., Rabbani, S., \& Hendriaana, H. (2019). Pendampingan Penyusunan Bahan Ajar Dengan Tema "Penerapan Pembelajaran Realistic Mathematic Education Menggunakan Barang Bekas ” pada Guru Sekolah Dasar Bantaran Sungai Citarum ( Program Pengabdian Di desa Dayeuhkolot Kecamatan Dayeuhkolot Kabupaten Daye. 02(d), 140-146.

Pangondian, R. A., Santosa, P. I., \& Nugroho, E. (2019). Faktor-Faktor Yang Mempengaruhi Kesuksesan Pembelajaran Daring Dalam Revolusi Industri 4.0. Seminar Nasional Teknologi Komputer \& Sains, 1.

Parmin, \& Peniati, E. (2012). Pengembangan Modul Mata Kuliah Strategi Belajar Mengajar IPA Berbasis Hasil Penelitian Pembelajaran. Jurnal Pendidikan IPA Indonesia, 1, 8-15. 
Pasaribu, I., Siagian, P., \& Amry, Z. (2018). The Differentiation of Improved Communication Mathematic and Disposition Skill Through Problem Based Learning and Realistic Mathematication Education. 200, 76-80. https://doi.org/10.2991/aisteel-18.2018.16

Putri, D. P. (2019). Pengembangan Bahan Ajar Matematika Berbasis RME untuk Mahasiswa Pgmi Di Iain Curup. Eduma: Mathematics Education Learning and Teaching. https://doi.org/10.24235/eduma.v8i1.4046

Ratnaningsih, N. (2008). Berbagai Keterampilan Berpikir Matematik. Seminar Pendidikan Matematika Di Universitas Siliwangi Tasikmalaya.

Rokhmani, T. A. (2016). Implementasi Pendidikan Karakter Peduli Lingkungan. Jurnal Pendidikan Guru Sekolah Dasar.

Rusdiana, E., \& Nugroho, A. (2020). Respon Mahasiswa Pada Pembelajaran Daring Bagi Mahasiswa Mata Kuliah Pengantar Hukum Indonesia UNESA. Integralistik, 31, 1-12. Streefland, L. (1991). Realistics Matematics Education in Primary School. Frudenthal Institute.

Sugiyono. (2006). MetodePenelitian Kuantitatif Kualitatif dan R\&D. Alfabeta.

Sumarmo, U. dkk. (2002). Alternatif Pembelajaran Matematika dalam Menerapkan Kurikulum Berbasis Kompetensi. Seminar Tingkat Nasional FPMIPA UPI Bandung.

Sunismi, S. (2015). Pengembangan Bahan Ajar Geometri Dan Pengukuran Berbasis Realistic Mathematics Education (RME) Untuk Siswa SMP Kelas VIII. JPM : Jurnal Pendidikan Matematika. https://doi.org/10.33474/jpm.v1i1.404

Suryani, Y. E. (2010). Kesulitan belajar. Magistra, 22, 33-40.

Tandililing, E. (2003). Implementasi Realistic Mathematic Education di Sekolah. Jurnal Matematika. https://doi.org/10.1007/978-94-007-4978-8_170

Ubaidillah, M. F., Subanji, \& Sa'dijah, C. (2014). Bahan Ajar Berbasis Realistic Mathematic Education (RME) Materi Opersi Hitung untuk Siswa Sekolah Dasar. Pascasarjana Universitas Negeri Semarang. 